\title{
A sustained felsic magmatic system: the Hercynian granitic batholith of the Spanish Central System
}

\author{
Carlos Villaseca and Víctor Herreros
}

\begin{abstract}
A batholith of around $10,000 \mathrm{~km}^{2}$ was formed during the Hercynian orogeny in the Spanish Central System (SCS). Geochronological data indicate concentrated magmatic activity during the period 325-284 Ma. This late-orogenic magmatism is essentially granitic with only minor associated basic rocks ( $<2 \%$ in outcrop). The SCS is a remarkably homogeneous batholith showing a restricted range of geochemical granite types without any evolutionary pattern related to time. These peraluminous granites show a limited variation in $\left.\mathrm{Na}_{2} \mathrm{O} / \mathrm{K}_{2} \mathrm{O}\right)(0 \cdot 60-0 \cdot 95)$, $\mathrm{K} / \mathrm{Rb}(140-240),(\mathrm{La} / \mathrm{Yb})_{\mathrm{n}}(6-13)$, and $\mathrm{Eu} / \mathrm{Eu}^{*}(0 \cdot 34-0 \cdot 62)$ ratios. This constancy in chemical characteristics is also reflected in their isotopic signatures: most monzogranites have initial ${ }^{87} \mathrm{Sr} /{ }^{86} \mathrm{Sr}$ ratios in the range of $0 \cdot 7073-0.71229$, initial $\varepsilon \mathrm{Nd}$ values vary between -5.4 and -6.6 and ${ }^{18} \mathrm{O}$ values group in the restricted range of $8 \cdot 9-9 \cdot 6 \%$. The lack of significant differences among SCS granitoids, maintained during a long geological period, suggests constancy in the nature of their source regions and conditions of magma generation. (1) Limited range of crustal sources: an essentially magmatic recycling during Hercynian orogen is suggested. Mantle-derived components are very limited and restricted to a minor role in the origin of the batholith. Geochemical and isotopic features of SCS granitoids are compatible with felsic lower crustal sources. (2) Constraints in melt conditions: uniformity in residual mineral assemblages (feldspars and garnet are always present in the granulitic residua) combined with a lack of attainment of equilibrium conditions during accessory phase dissolution in the crustal melting process is suggested. Granitic melts never reach saturation in some trace elements (REE, Th, Y, Zr), restricting their chemical variability. (3) Homogenisation in magma chambers: long-lived magmatic systems whose successive pulses accumulate into large magma chambers have the opportunity to mingle, thus reducing source differences.
\end{abstract}

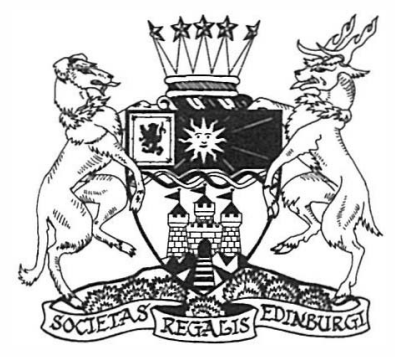

KEY WORDS: collision granites, crustal anatexis, geochemistry, Hercynian Iberian Belt, isotopes, peraluminous batholith

A voluminous batholith of around $10,000 \mathrm{~km}^{2}\left(\sim 100,000 \mathrm{~km}^{3}\right)$ was built during the Hercynian orogeny in the innermost continental region of the Iberian Belt, the Spanish Central System (SCS). The batholith is made of more than 100 intrusive units, mainly monzogranite in modal composition, that were emplaced during a time span of around $40 \mathrm{Ma}$ (Villaseca et al. 1995). Granitoids are the dominant rock in the SCS region, forming more than $85 \%$ of the outcropping surface in most parts. This batholith defines a clear geographical and geological unit separated by Precambrian and pre-Ordovician metamorphic series from western Hercynian granitic belts, not studied in this work. Nevertheless, the granitic belt of $\mathrm{S}$ Toledo, separated by Cenozoic sedimentary rocks of the Tagus basin, seems to be related to this central granitic block (Fig. 1).

The geochemical and petrological data set was collected during the last two decades by different authors in the three main sectors of the batholith: the eastern Sierra de Guadarrama (Brandebourger 1984; Casillas 1989; Pérez-Soba 1991; Villaseca et al. 1993; Villaseca et al. 1998a), the central Gredos Massif (Bea 1985; Moreno-Ventas et al. 1995; Herreros 1998) and the western Sierra de Béjar (Rottura et al. 1989; Recio et al. 1992; Pinarelli \& Rottura 1995). With all these data, it is possible to envisage a remarkably homogeneous granitic batholith. Several models have been proposed to explain the origin of the SCS granites: (a) partial melting of essentially crustal sources (Villaseca et al 1998a; Bea et al. 1999); (b) hybridisation between crustal melts and mantle-derived magmas (Pinarelli \& Rottura 1995; Moreno-Ventas et al. 1995); (c) crustal assimilation after hybridisation (Ugidos \& Recio 1993).

The aim of this work is to emphasise the long-term magmatic geochemical patterns in the SCS batholith when compared with other granitic batholiths from different geodynamical settings: plate margins, intracontinental rifts or other collision-related granitoids. Melting of felsic lower crustal levels is proposed as the origin for this long-lived felsic and geochemically homogeneous magmatism.

\section{The Hercynian plutonic event}

The Hercynian orogeny is considered to have begun in this region just before the interruption of the Paleozoic sedimentation in lower to middle Devonian times (408-387 Ma., Gutiérrez Marco et al. 1990). This age is close to that given by some discordant $\mathrm{U}-\mathrm{Pb}$ zircon data in SCS metamorphic rocks, which give lower concordia intercepts around 380$370 \mathrm{Ma}$ (Wildberg et al. 1989). No more sedimentation occurred in the sector until the local deposition of upper Stephanian detrital rocks with associated volcanics (dated as 287 Ma volcanism, Hernando et al. 1980), related to distensive tectonic basins of the eastern SCS domains. This age range of c. 100-120 Ma encompasses most Hercynian radiometric magmatic, metamorphic and cooling ages of the SCS. 


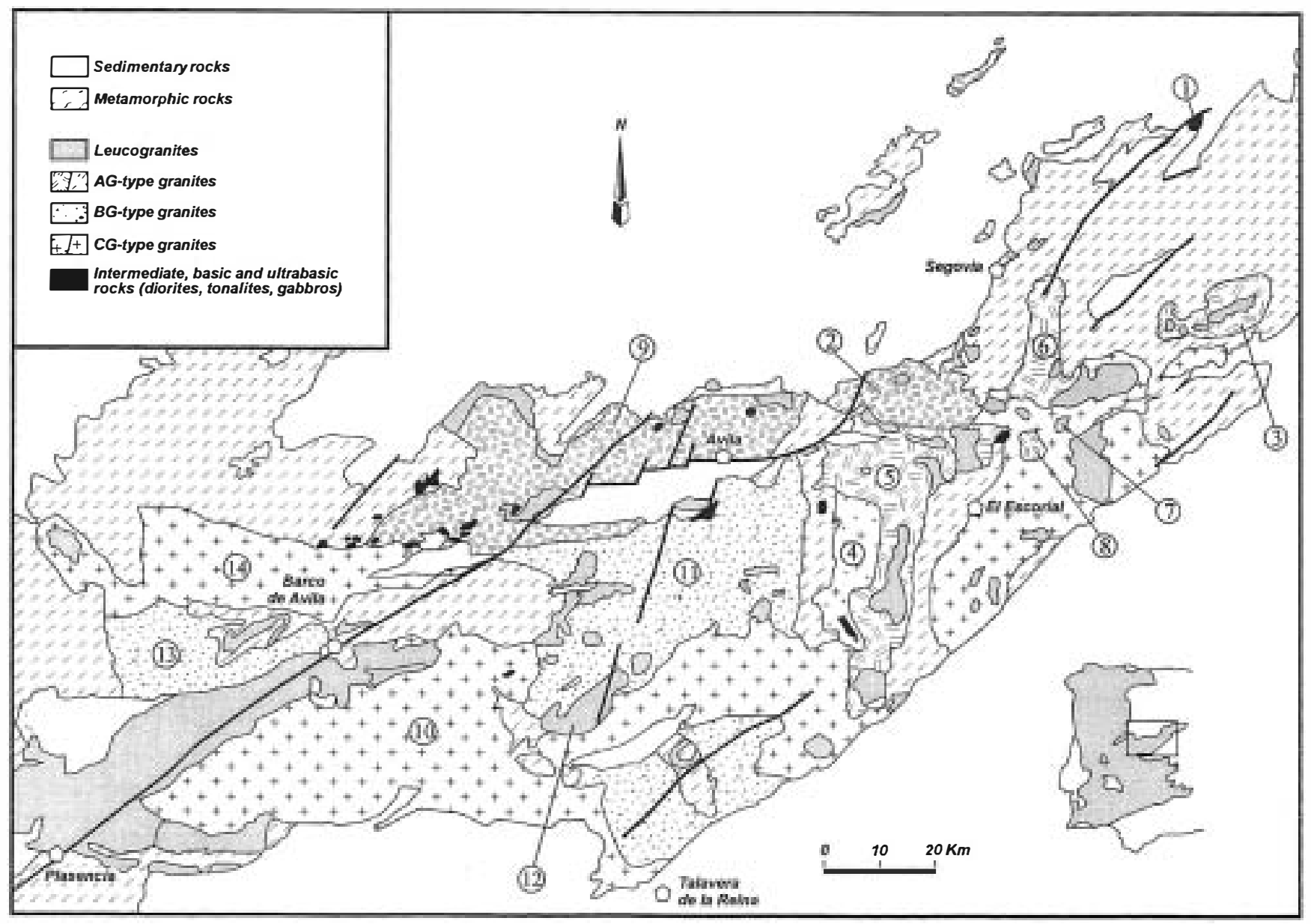

Figure 1 Geological sketch map of the Spanish Central System (SCS) and its location in the Hercynian Iberian Belt; granite-types in the legend are: AG-type = biotite granites with local accessory amphibole; $\mathrm{BG}$-type $=$ biotite granite sensu stricto; CG-type = biotite granites with accessory cordierite. Further explanation in section 2 of the text. Key to plutons: 1, Ventosilla; 2, Villacastin; 3, La Cabrera; 4, Hoyo de Pinares; 5, Navas del Marqués; 6, La Granja; 7, Cabeza Mediana; 8, Atalaya Real; 9, Cardeñosa-Avila; 10, Hoyos del Espino; 11, Navalosa; 12, Pedrobernardo; 13, Bé jar BG; 14, Bé jar CMG

Hercynian tectonothermal evolution in the SCS is far from being well constrained. Nevertheless, most previous works describe a classical clock-wise P-T-t evolution of the Proterozoic and Palaeozoic rocks due to orogenic crustal thickening (Pereira 1992; Escuder Viruete et al. 1998). A first deep burial phase that reached eclogite/high-P granulite facies (Villaseca \& Barbero 1994) was followed by a low-P/high-T event with widespread partial melting of the middle crust (resulting in migmatitic granulite-facies terranes such as those described by Pereira 1992; Barbero 1995; Martín Romera et al. 1999). Geochronology of this P-T evolution is poorly constrained; some concordant $\mathrm{U}-\mathrm{Pb}$ monazite data in metasediments and felsic metaigneous rocks in the Guadarrama sector give ages in the range $337-326 \mathrm{Ma}$ for the metamorphic peak in eastern Guadarrama (Escuder Viruete et al. 1998). Nevertheless, the metamorphic climax in the nearby Toledo granulitic areas is dated at c. $310 \mathrm{Ma}$ (Barbero \& Rogers 1999), suggesting a certain diachronism of the Hercynian metamorphic peak in central Spain.

Granitic plutonism mostly postdates the main tectonometamorphic events. This plutonism occurred $c$. $60 \mathrm{Ma}$ after the beginning of the collision, but only $10 \mathrm{Ma}$ after the midcrustal emplacement levels reached metamorphic peak conditions. The granites are discordant with the surrounding rocks and produced contact aureoles. Plutonic magmatism is mainly concentrated in the range $323-284 \mathrm{Ma}$ (Bea et al.
1994; Villaseca et al. 1995; Herreros 1998) although recent $\mathrm{Rb}-\mathrm{Sr}$ geochronology in the easternmost pluton (Ventosilla) gives the oldest recorded age $(343 \mathrm{Ma})$ for SCS intrusives (Villaseca et al. 1998b). Figure 2 shows the relationship of emplacement ages with the spatial distribution of major plutonic units in the eastern side of the batholith, where geochronological studies are more abundant. In this figure it is possible to discern that most of the batholith was built during the 323-303 Ma period with residual magmatic activity for another $20 \mathrm{Ma}$. This residual magmatism consists of small highly felsic plutons, usually less than $50 \mathrm{~km}^{2}$ in surface area, and of coeval granitic porphyry dyke swarms (Fig. 2). Although available geochronological data (mainly based on $\mathrm{Rb}-\mathrm{Sr}$ whole-rock isochrons) are still scarce (only 17 plutons are dated), the available results seem to be representative of the whole batholith as most of the dated plutons are major intrusive complexes $\left(>150 \mathrm{~km}^{2}\right.$, Table 1$)$. According to the current geological and geochemical data set some granites (AG-types) seem to be more concentrated in the northern side of the batholith (Fig. 1), but this needs to be studied in more detail in future works.

At the present level of exposure, the Hercynian SCS intrusive rocks are predominantly granitoids with rare gabbroids and intermediate rock types which cover less than $10 \mathrm{~km}^{2}$ (Bea 1985; Villaseca et al. 1998a). Scarce geochronological data on these rare basic-intermediate massifs (Gredos massif. $340 \mathrm{Ma}$, 


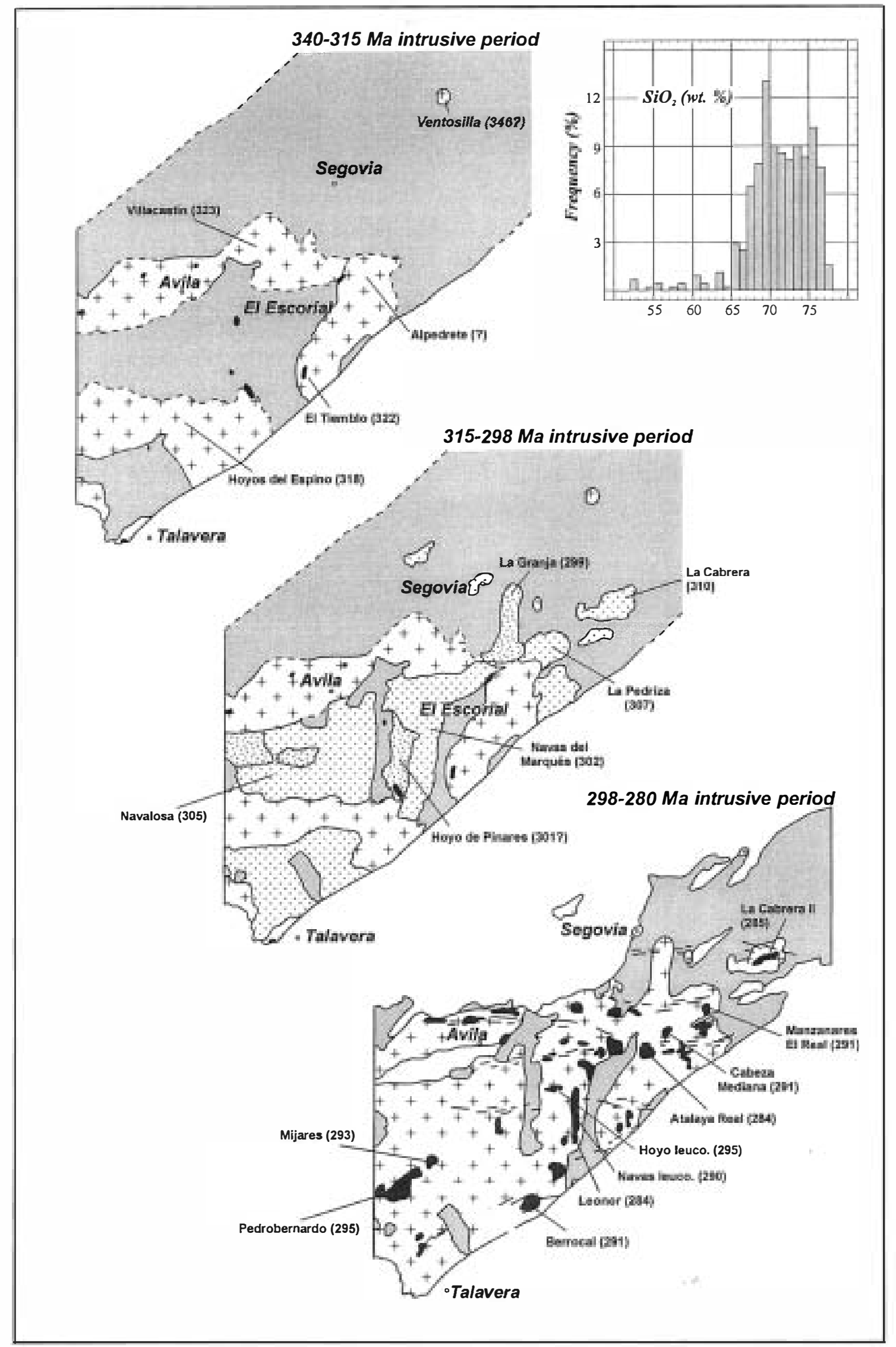

Figure 2 Temporal sequence of intrusive units in the SCS during the Hercynian orogeny; geochronological data are mostly based in $\mathrm{Rb}-\mathrm{Sr}$ whole-rock isochrons (see references in Table 1); inset shows a histogram of $\mathrm{SiO}_{2}$ content of the SCS granitoids $(n=450)$. 
Table 1 General features and averaged geochemical values of SCS monzogranitic plutons

\begin{tabular}{|c|c|c|c|c|c|c|c|c|c|c|c|c|}
\hline Sector & Granite-type & Pluton & $\begin{array}{l}\text { Surface } \\
\left(\mathrm{km}^{2}\right)\end{array}$ & $\begin{array}{l}\text { Age } \\
\text { (Ma) }\end{array}$ & $\mathrm{Na}_{2} \mathrm{O} / \mathrm{K}_{2} \mathrm{O}$ & $\mathbf{K} / \mathbf{R b}$ & Sr (ppm) & $\mathbf{E u} / \mathbf{E u}$ * & $(\mathrm{La} / \mathrm{Yb})_{\mathrm{n}}$ & $\left({ }^{87} \mathrm{Sr} /{ }^{86} \mathrm{Sr}\right)_{\mathrm{t}}$ & $\varepsilon \mathbf{N d}_{\mathrm{t}}$ & $\delta^{18} \mathrm{O}$ \\
\hline Eastern SCS (Guadarrama) & AG (PI) & Ventosilla & 2 & $346 ?$ & $1 \cdot 30 \pm 0 \cdot 3$ & $226 \pm 34$ & $320 \pm 40$ & $0 \cdot 87 \pm 0 \cdot 2$ & $9 \cdot 2 \pm 0 \cdot 4$ & 0.70869 & $-5 \cdot 4-5 \cdot 8$ & \\
\hline Eastern SCS (Guadarrama) & AG (PI) & Villacastin & $>150$ & 323 & $0 \cdot 80 \pm 0 \cdot 2$ & $181 \pm 28$ & $150 \pm 15$ & $0.50 \pm 0.1$ & $9 \cdot 25 \pm 1 \cdot 75$ & $0 \cdot 7073$ & $-5 \cdot 53$ & $9 \cdot 3$ \\
\hline Eastern SCS (Toledo) & CG (PS) & Mora-Ventas & 515 & 320 & $0.78 \pm 0.06$ & $155 \pm 15$ & $120 \pm 30$ & $0.52 \pm 0.07$ & $6 \cdot 8 \pm 0 \cdot 5$ & $0 \cdot 7103$ & $-6 \cdot 37$ & \\
\hline Eastern SCS (Guadarrama) & BG (Trans.) & Sierra del Francés & 28 & 315 & $0 \cdot 81 \pm 0.04$ & $170 \pm 20$ & $95 \pm 10$ & $0 \cdot 70-0 \cdot 73$ & $8 \cdot 5 \pm 0 \cdot 9$ & $0 \cdot 7088$ & $-7 \cdot 7$ & \\
\hline Eastern SCS (Guadarrama) & $A G(P I)$ & La Cabrera & 160 & 310 & $0.85 \pm 0.08$ & $219 \pm 13$ & $170 \pm 29$ & $0.45 \pm 0.05$ & $10 \cdot 7 \pm 1 \cdot 65$ & $0 \cdot 7094$ & $-6 \cdot 53$ & \\
\hline Eastern SCS (Guadarrama) & CG (PS) & Hoyo de Pinares & $>130$ & 301 & $0.73 \pm 0.07$ & $175 \pm 25$ & $100 \pm 15$ & $0.59 \pm 0.09$ & $8 \cdot 7 \pm 0.4$ & $0 \cdot 7100$ & $-5 \cdot 22$ & \\
\hline Eastern SCS (Guadarra,a) & $\mathrm{AG}(\mathrm{PI})$ & Navas Marqués & 300 & 302 & $0.77 \pm 0.07$ & $179 \pm 22$ & $89 \pm 24$ & $0 \cdot 50 \pm 0 \cdot 14$ & $8 \cdot 3 \pm 4 \cdot 3$ & $0 \cdot 7097$ & $-5 \cdot 1-5 \cdot 5$ & \\
\hline Eastern SCS (Guadarrama) & CG (PS) & Alpedrete & 350 & $300 ?$ & $0.85 \pm 0.05$ & $180 \pm 25$ & $160 \pm 30$ & $0.50 \pm 0.05$ & $9 \cdot 9 \pm 1 \cdot 2$ & 0.70896 & $-6 \cdot 31$ & $9 \cdot 4-9 \cdot 5$ \\
\hline Eastern SCS (Guadarrama) & AG (PI) & La Granja & 85 & 299 & $0.79 \pm 0.12$ & $186 \pm 17$ & $130 \pm 30$ & $0.44 \pm 0.08$ & $9 \cdot 1 \pm 1 \cdot 25$ & 0.71212 & $-6 \cdot 49$ & \\
\hline Eastern SCS (Guadarrama) & CG (PS) & Cabeza Mediana* & 7 & 291 & $0 \cdot 89$ & 172 & 95 & 0.45 & $7 \cdot 9$ & 0.71127 & $-6 \cdot 64$ & $9 \cdot 5$ \\
\hline Eastern SCS (Guadarrama) & AG (PI) & Atalaya Real & 18 & 284 & $0 \cdot 75 \pm 0.03$ & $197 \pm 4$ & $149 \pm 18$ & $0 \cdot 50 \pm 0 \cdot 1$ & $11 \cdot 7 \pm 3 \cdot 25$ & 0.7128 & $-6 \cdot 00$ & $8 \cdot 9-9 \cdot 1$ \\
\hline Central SCS (Gredos) & AG (PI) & Cardeñosa-Avila & $>150$ & $321 ?$ & $0.91 \pm 0.03$ & & $170 \pm 26$ & $0 \cdot 66 \pm 0 \cdot 1$ & $8 \cdot 50 \pm 2 \cdot 72$ & & & $8.9 \pm 0.6$ \\
\hline Central SCS (Gredos) & CG (PS) & Hoyos del Espino & $>300$ & 318 & $0.62 \pm 0.05$ & $180 \pm 15$ & $145 \pm 20$ & & & $0 \cdot 7084$ & $-6 \cdot 1-6 \cdot 3$ & \\
\hline Central SCS (Gredos) & BG (Trans.) & Navalosa & 820 & 305 & $0.81 \pm 0.03$ & $187 \pm 25$ & $150 \pm 25$ & $0.52-0.67$ & $11 \cdot 35 \pm 3 \cdot 5$ & $0 \cdot 7083$ & $-4 \cdot 0-7 \cdot 1$ & $9 \cdot 8$ \\
\hline Central SCS (Gredos) & CG (PS) & Pedrobernardo* & 45 & 295 & $0.60 \pm 0.02$ & $151 \pm 5$ & $95 \pm 6$ & $0 \cdot 30 \pm 0 \cdot 1$ & $23 \cdot 1 \pm 2 \cdot 5$ & $0 \cdot 7123$ & & \\
\hline Western SCS (Béjar) & BG (Trans.) & Béjar BG & $>150$ & $316 ?$ & $0 \cdot 81 \pm 0.03$ & $188 \pm 15$ & $151 \pm 29$ & $0 \cdot 53 \pm 0 \cdot 1$ & $9 \cdot 95 \pm 3.69$ & $\begin{array}{l}0 \cdot 70838- \\
0 \cdot 70910\end{array}$ & $-3.9-8 \cdot 0$ & $9 \cdot 0 \pm 0 \cdot 4$ \\
\hline Western SCS (Béjar) & CG (PS) & Bćjar CMG & $120 ?$ & $307 ?$ & $0.77 \pm 0.03$ & $153 \pm 30$ & $159 \pm 30$ & $0 \cdot 50 \pm 0 \cdot 1$ & $11.68 \pm 3.37$ & $\begin{array}{l}0 \cdot 70799- \\
0 \cdot 70897\end{array}$ & $-4 \cdot 7-7 \cdot 8$ & $9 \cdot 6 \pm 0 \cdot 3$ \\
\hline
\end{tabular}

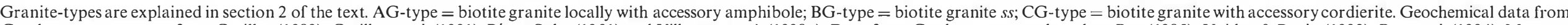

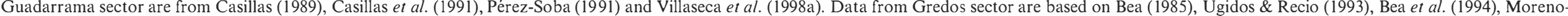

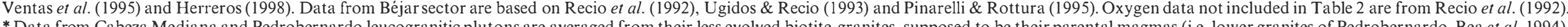

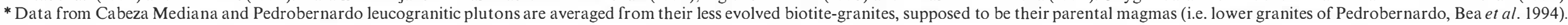


Bea et al. 1999; El Tiemblo massif. 322 Ma, Casillas et al. 1991) corroborate their geological interpretation as being either previous or related to the first pulse of the granite plutonism in this area. Moreover, basic magmas are also coeval to granite porphyry dyke intrusive events. So, minor basic intrusions were emplaced during most of the Hercynian magmatism.

The major intrusive units are composed of monzogranites (around $75 \%$ of the SCS granitoids) that locally grade to granodiorites (around $9 \%$ of granitoids), forming the socalled regional granites. The leucogranites (the other $16 \%$ of SCS granitoids) usually intrude as small units in the other granitoids, and they are commonly interpreted as highly fractionated magmas derived from the monzogranitic parental magmas (Bellido 1979; Casillas 1989; Villaseca et al. 1998a). The SCS batholith is monzogranitic on average.

\section{SCS granite-types}

The SCS batholith is almost entirely composed of peraluminous granitoids (Fig. 3). Three different granite-types have been distinguished. Petrographically they are biotite granites (as this mica is the main mafic phase in all the SCS monzogranites), but slightly modal differences between them could be found. The first type is composed of cordierite-bearing granites, which are moderately peraluminous granitoids in the sense of Villaseca et al. (1998c), and they have also received other names such as PS (for their affinity to some S-type granites, e.g. Dalgety suite of Chappell et al. 1991) (Villaseca et al. 1998a) or CG/CMG-types in the western sector of the SCS (Recio et al. 1992; Pinarelli \& Rottura 1995). The second type is composed of metaluminous to weakly peraluminous granitoids, with locally accessory amounts of amphibole and allanite as index minerals, also called PI or AG-types by different authors (Villaseca et al. 1998a; Recio et al. 1992). A third transitional type, composed of biotite granitoids (sensu stricto) of intermediate peraluminous character, without peraluminous characteristic minerals, could be distinguished (BG-types of Recio et al. 1992; Pinarelli \& Rottura 1995). For simplicity, in this work we use the descriptive terms CG-types (cordieritebearing granites), BG-types (biotite granites) and AG-types (amphibole-bearing granites).

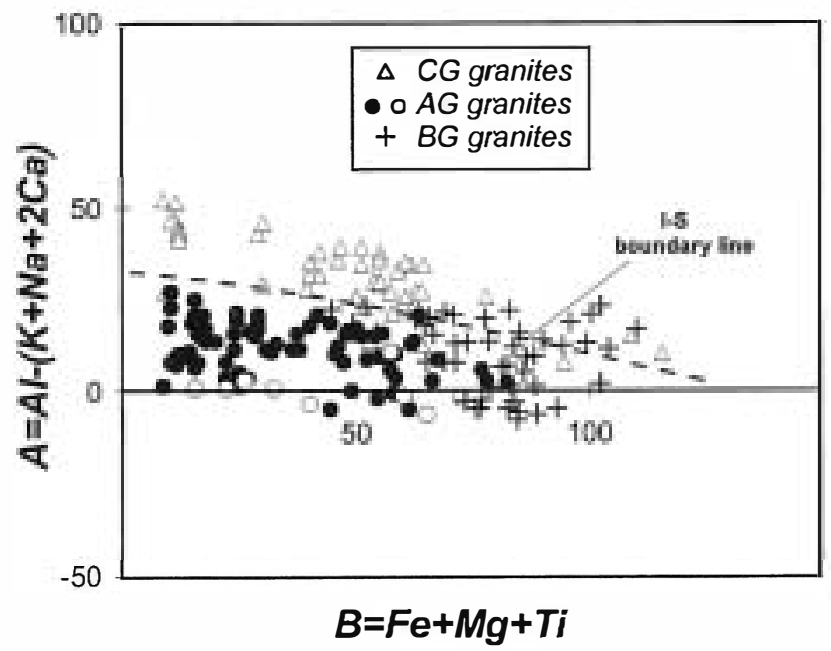

Figure 3 A-B parameters (see Debon \& Le Fort 1983) for selected SCS granite-types; BG granites from Navalosa pluton (Herreros 1998) plot in intermediate fields between AG and CG-types; the less peraluminous suite of AG granites correspond to those of Atalaya Real pluton (open circles); I-S boundary line taken from Villaseca et al. (1998c).

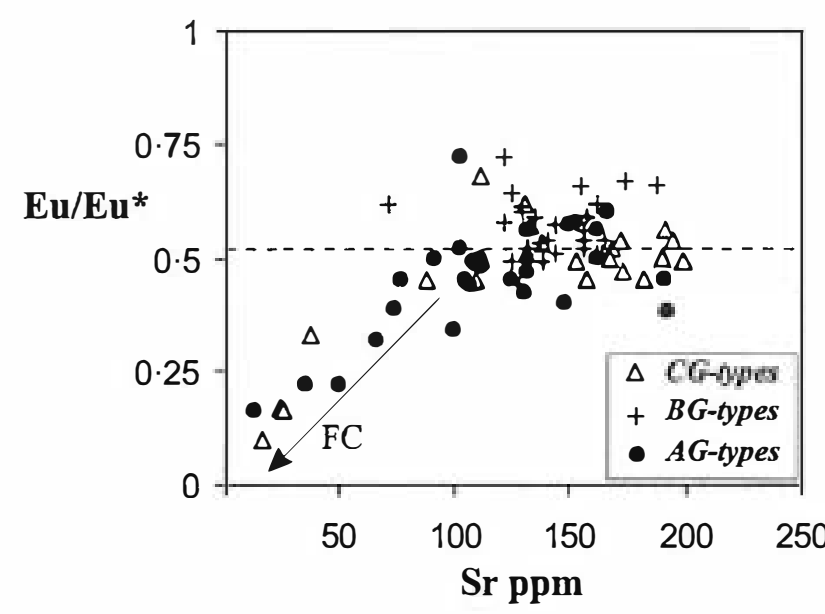

Figure 4 Variation of the Eu anomaly $\left(\mathrm{Eu} / \mathrm{Eu}^{*}\right)$ with $\mathrm{Sr}$ content for SCS granite-types; lower $\mathrm{Sr}$ contents and larger $\mathrm{Eu}$ anomalies correspond to more leucogranitic samples, a common feldspar fractionation trend shown by SCS granite-types (FC trend); Eu anomaly in parental monzogranites is mostly in the range $0.45-0.65$, at $c .150 \pm$ $50 \mathrm{ppm} \mathrm{Sr}$, suggesting the presence of residual feldspars in the granulitic source (see text for further explanation).

SCS granites are mostly in the range $67 \cdot 5-76 \cdot 5 \mathrm{wt} . \%$ silica content and monzogranitic in composition, with around $70 \pm$ $2 \mathrm{wt} . \%$ as the most frequent value (inset in Fig. 2). The majority of the SCS granites are peraluminous but some AG plutons are clearly subaluminous (e.g. Atalaya Real pluton, Fig. 3). Subtle higher $\mathrm{Ca}, \mathrm{Na}, \mathrm{REE}, \mathrm{Th}, \mathrm{Y}$ and $\mathrm{Zr}$ contents and lower $\mathrm{P}, \mathrm{Al}$ and $\mathrm{Nb}$ contents in AG-types with respect to more peraluminous granites have been described (Casillas 1989; Villaseca $e t$ al. 1998a). At c. $73-75 \% \mathrm{SiO}_{2}$ content, SCS granites describe an inflection in geochemical trends in most of their plots. This has been interpreted and modelled as the result of the evolution of these suites by fractional crystallisation (Casillas 1989; Villaseca et al. 1998a). Feldspar fractionation is a common process during the evolution of SCS magmas, as shown by the decreasing $\mathrm{Sr}$ contents and increasing Eu anomaly in the more evolved rocks (Fig. 4). A compositional variation from granodiorite to leucogranite is recognised in plutons of the three described typologies, suggesting similar evolutionary patterns, but transitions from one granite-type to another in the same pluton have not been described. In fact, more complex fractionation trends with divergent evolution lines between AG and CG-types have been described elsewhere (e.g. Villaseca $e t$ al. 1998a), as illustrated in other peraluminous granitic suites (Chappell 1999).

\section{Geochemical patterns with time: homogeneous vs heterogeneous batholiths}

When comparing granitoids on a regional basis, it is important to eliminate the effects of magmatic differentiation. In order to compare similar lithologies, we have only used rock compositions bracketed by $\mathrm{SiO}_{2}$ values of $67 \cdot 5-72 \mathrm{wt} . \%$, representative of the dominant monzogranitic regional facies of the different plutonic complexes of the area, also described as granite parents of the whole pluton (e.g. Casillas 1989; Bea et al. 1994). When comparing the averaged geochemical values summarised in Table 1, the SCS granites show a small range of variation in some major and trace element ratios, and also in isotopic ratios (Fig. 5). However, some small plutons plot outside the general trend (Fig. 5). So, data from one of the most felsic plutons of the sector (Pedrobernardo pluton, Bea 

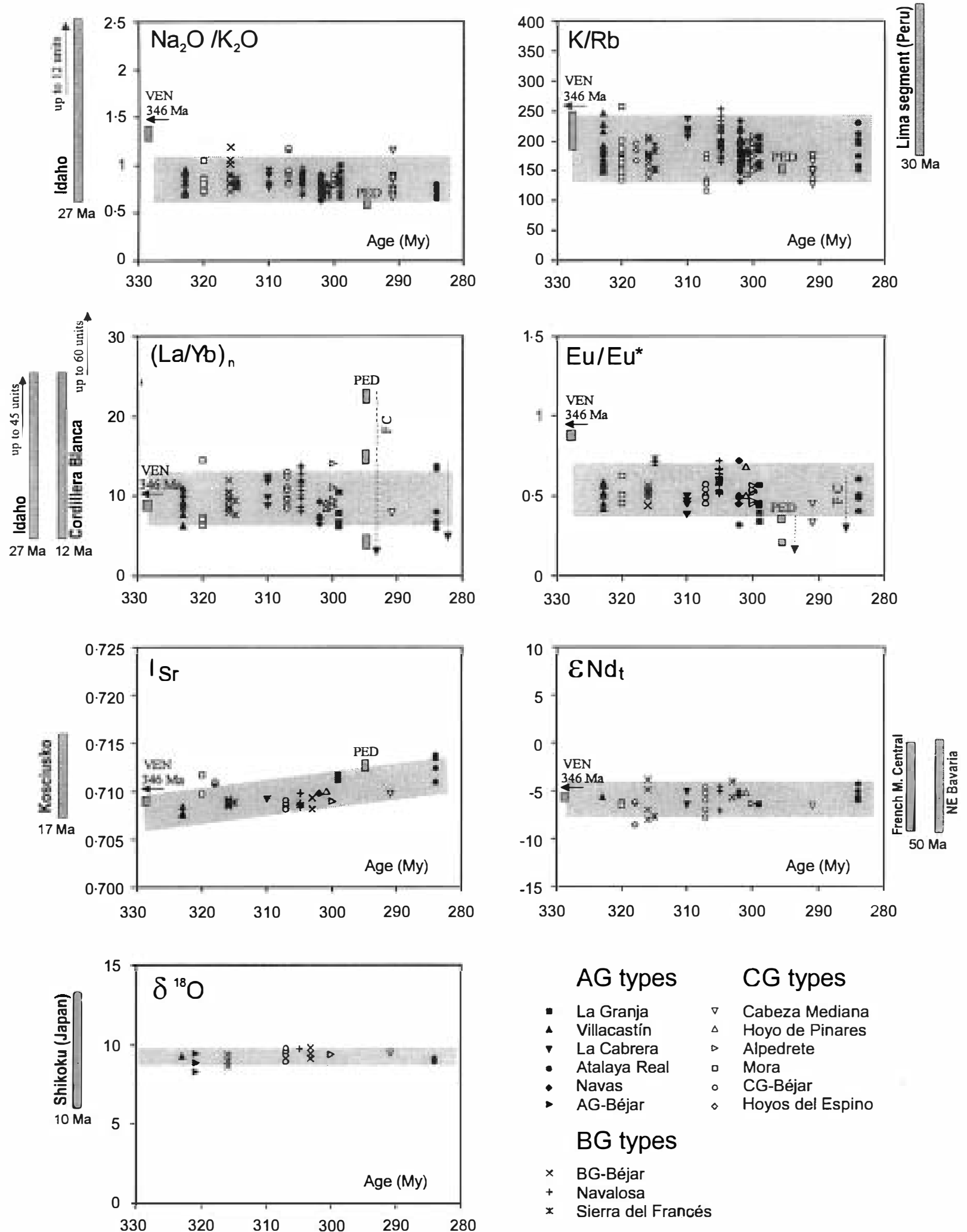

Figure 5 A summary of compositional parameters for the SCS batholith, illustrating the relative homogeneity in magma composition with time; data for the tonalitic Ventosilla pluton (VEN) (346 Ma in age) and the felsic Pedrobernardo pluton (PED) (295 Ma) are also shown, plotting outside the general range in some of the diagrams; the effect of feldspar fractionation in a plutonic suite is also shown in some of the plots (FC trend); with the exception of certain plutons, most of the SCS batholith shares some common geochemical features in comparison to other more complexly constructed batholiths (see also text); geochronological and chemical features for SCS granites are from Table 1; chemical bars and approximated time span of construction from other batholiths are: Idaho (Norman et al. 1992), Lima segment (Atherton et al. 1979), Cordillera Blanca (Petford \& Atherton 1996), French Massif Central (Pin \& Duthou 1990), NE Bavaria (Siebel et al. 1995), Kosciusko (Chappell et al. 1991) and Shikoku Island, SW Japan (Ishihara \& Matsuhisa 1999). 
et al. 1994, see Table 1) display a distinctive granite parent with a low $\mathrm{Na}_{2} \mathrm{O} / \mathrm{K}_{2} \mathrm{O}$ ratio and more fractionated REE pattern (Fig. 5). These geochemical features combined with a high initial ${ }^{87} \mathrm{Sr} /{ }^{86} \mathrm{Sr}$ ratio were interpreted by Bea et al. (1994) as granites derived from metasedimentary sources. Also, the tonalitic-granodioritic samples of the Ventosilla pluton show a greater range of values in $\mathrm{Na}_{2} \mathrm{O} / \mathrm{K}_{2} \mathrm{O}$ and $\mathrm{Sr}$ contents, and REE patterns with much lesser negative $\mathrm{Eu}$ anomalies than other SCS granites. Again, this suggests certain differences in the source-region characteristics. Nevertheless, other geochemical features of the Ventosilla pluton (including initial $\mathrm{Sr}$ and $\mathrm{Nd}$ isotopic ratios) are in the range of the SCS granites (Fig. 5).

SCS monzogranitic types show a restricted range of initial $\varepsilon \mathrm{Nd}$ from -4 to -8 (but most values are between -5.4 to $-6 \cdot 6$, Table 1), and also exhibit a limited range in initial ${ }^{87} \mathrm{Sr} /{ }^{86} \mathrm{Sr}$, averaged from 0.7073 to 0.7129 (Pérez Soba 1991; Casillas et al. 1991. Moreno-Ventas et al. 1995; Pinarelli \& Rottura 1995; Villaseca et al. 1998a; Herreros 1998). Only local hybridised facies richer in conspicuous mafic microgranular enclaves, show a more primitive and varied $\mathrm{Sr}, \mathrm{Nd}$ isotopic composition (Moreno-Ventas et al. 1995; Villaseca et al. 1998a). Initial $\mathrm{Sr}$ isotopic ratios slightly increase with time but the trend follows an evolutive pattern for $\mathrm{Rb} / \mathrm{Sr}$ ratios in the range $1-5$, which are typical crustal values. A higher variability in the fractionation of the $\mathrm{Rb} / \mathrm{Sr}$ ratio during crustal anatexis and also a higher modification of $\mathrm{Sr}$ values with time in comparison to $\mathrm{Nd}$ isotopic compositions, could be involved in the origin of the higher $\mathrm{Sr}$ isotopic heterogeneity shown by the SCS granites.

Preliminary $\delta^{18} \mathrm{O}$, and $\mathrm{Pb}$ (for feldspars) isotopic data also reinforce the similarities among the analysed SCS granitoids.
Five plutons from the eastern SCS (around La Pedriza pluton in the Guadarrama sector, Fig. 2) present $\mathrm{Pb}$ isotopic ratios within a narrow range: ${ }^{206} \mathrm{~Pb} /{ }^{204} \mathrm{~Pb}=18 \cdot 33,{ }^{207} \mathrm{~Pb} /{ }^{204} \mathrm{~Pb}=$ $15 \cdot 59-15 \cdot 62,{ }^{208} \mathrm{~Pb} /{ }^{204} \mathrm{~Pb}=38 \cdot 15-38 \cdot 28$ (Pérez Soba 1991). These tightly clustered values plot in the middle of the $\mathrm{Pb}$ isotopic linear array shown by western European Hercynian granites (Downes et al. 1997) in a field which is suggestive of involvement of lower crustal sources. Similarly, the three granite types in the western area give almost identical wholerock $\delta^{18} \mathrm{O}$ values, in the range $8 \cdot 9-9 \cdot 6 \%$ (Recio et al. 1992). For these reasons the SCS granites have been interpreted as being derived from distinct magma batches from a restricted range of parent sources (Villaseca et al. 1998a).

\section{Magma sources}

The Hercynian plutons do not have their sources in the neighbouring wall rocks. The intrusive granitoids show similar geochemistry over the entire region irrespective of the adjacent wall rock composition and metamorphic grade. Moreover, isotopic compositions of metamorphic wall rocks (Fig. 6) are clearly different than those of the granites (Recio et al. 1992; Villaseca et al. 1998a). Much of the actual debate on SCS granite petrogenesis is explained in terms of a mixed mantle--crustal source (Recio et al. 1992; Moreno-Ventas et al. 1995; Pinarelli \& Rottura, 1995; Castro et al. 1999) or a mainly lower crustal origin (Villaseca et al. 1998a; Bea et al. 1999; Villaseca et al. 1999).

For this study we have performed new oxygen isotopic analyses of granites from the central and eastern areas of the SCS batholith and also of potential protoliths (Table 2).
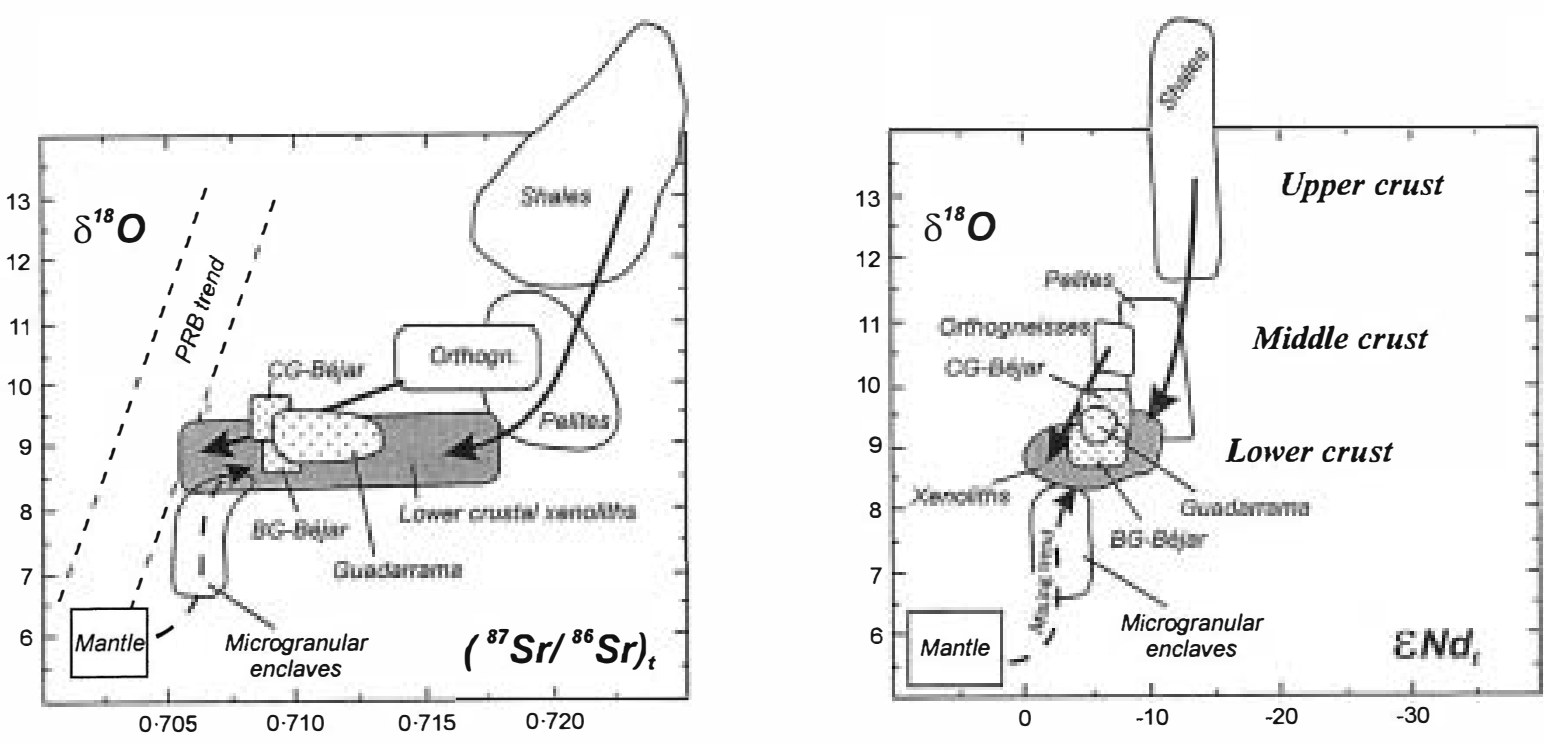

Figure 6 Plots of initial $\left({ }^{87} \mathrm{Sr} /{ }^{86} \mathrm{Sr}\right)$ and $\varepsilon_{\mathrm{Nd}}$ values vs $\delta^{18} \mathrm{O}$ values for SCS granites and surrounding Hercynian rocks: initial values for metamorphic rocks are calculated assuming an averaged Hercynian age of $300 \mathrm{Ma}$; granitic rocks plot mostly within the lower crustal xenoliths field, suggesting their deep crustal provenance; metamorphic rocks show a marked lowering in their isotopic ratios with depth, as has also been proposed for other crustal sections (see also Villaseca et al. 1999, and references therein); this isotopic shift of crustal lithotypes has to be considered when comparing granites with their surrounding metamorphic rocks; microgranular enclaves in SCS granites plot in an intermediate field between granites and mantle-derived magmas, suggesting chemical interactions between the two; see text for further explanations; mantle composition and the Peninsular Ranges Batholith (PRB) trend are also shown for comparison (Taylor 1988); data of Béjar granites are from Recio et al. (1992) (oxygen isotopes) and Pinarelli \& Rottura (1995) ( $\mathrm{Sr}, \mathrm{Nd}$ isotopes); data of epizonal precambrian shales of the Central Iberian Zone are from Ugidos et al. (1997); microgranular enclaves isotopic range is extrapolated from Recio et al. (1992), Pinarelli \& Rottura (1995) and Moreno-Ventas et al. (1995); Sr-Nd isotopic data of lower crustal xenoliths (shaded field) are from Villaseca et al. (1999); Sr-Nd data of SCS granites and wall-rocks (orthogneisses and pelites) are from Villaseca et al. (1998a); other oxygen data are from Table 2. 
Table 2 Oxygen isotope values (in per mil) on whole-rocks samples of the SCS batholith and related metamorphic rocks.

\begin{tabular}{|c|c|c|}
\hline Sample & Description & $d^{11} \mathrm{O}$ \\
\hline \multicolumn{3}{|c|}{ SCS granitoids } \\
\hline 92460 & AG-type. Granodiorite. Villacastín pluton & $9 \cdot 3$ \\
\hline HV 555-355 & $B G$-type. Monzogranite. Navalosa pluton & $9 \cdot 8$ \\
\hline 95916 & CG-type. Monzogranite. Alpedrete pluton & $9 \cdot 4-9 \cdot 5$ \\
\hline 76873 & $\begin{array}{l}\text { CG-type. Monzogranite. Cabeza Mediana } \\
\text { pluton }\end{array}$ & $9 \cdot 5$ \\
\hline 95922 & $\begin{array}{l}\text { AG-type. Granodiorite. Atalaya Real } \\
\text { pluton }\end{array}$ & $8 \cdot 9-9 \cdot 1$ \\
\hline \multicolumn{3}{|l|}{ Wall-rocks } \\
\hline 62978 & Augen orthogneiss & $10 \cdot 9$ \\
\hline 100942 & Augen orthogneiss & $10 \cdot 1-10 \cdot 4$ \\
\hline 77758 & Metapelite & $9 \cdot 1-9 \cdot 3$ \\
\hline 93202 & Pelitic migmatite & $11 \cdot 0$ \\
\hline 93201 & Pelitic migmatite & $11 \cdot 4$ \\
\hline \multicolumn{3}{|c|}{ Granulitic xenoliths } \\
\hline 81846 & Felsic metaigneous & $8 \cdot 9-9 \cdot 3$ \\
\hline 95148 & Felsic metaigneous & $8 \cdot 7-8.9$ \\
\hline $\mathrm{U}-50$ & Felsic metaigneous & $8 \cdot 3$ \\
\hline U-93 & Felsic metaigneous & $8 \cdot 9$ \\
\hline 77750 & Metapelite & $9 \cdot 1-9 \cdot 6$ \\
\hline
\end{tabular}

Oxygen isotopic ratios were measured by $C$. Recio in the Servicio General de Análisis de Isótopos Estables de la Universidad de Salamanca following the method described in Recio et al. (1992).

In Figure 6 it is possible to observe that lower crustal xenoliths perfectly match (in terms of $\mathrm{Sr}, \mathrm{Nd}$ and oxygen isotopic ratios) the compositional range of SCS granites. The felsic (mostly metaigneous in origin) granulite xenoliths have initial $\mathrm{Sr}$ isotope ratios in the range $0.706-0.713 \varepsilon \mathrm{Nd}$ values from -2.6 to $-8 \cdot 2$ (Villaseca et al. 1999) and $\delta^{18} \mathrm{O}$ values of $8 \cdot 7-9 \cdot 3 \%$ (Table 2). In view of the residual character of these granulites, from which granitic melts similar in composition to those of outcropping granites have been extracted (Villaseca et al. 1999), a mainly lower crustal origin for most of the batholith could be deduced. Moreover, the new oxygen isotope data presented in this work reinforce the geochemical similarity between the defined SCS granitic series and their lower crustal sources (residual granulites).

In Figure 6 the $\mathrm{Sr}, \mathrm{Nd}$ and oxygen isotopic compositional range of mafic microgranular enclaves (MME) from the Bejar granites (Recio et al. 1992; Pinarelli \& Rottura 1995) and Gredos granites (Moreno-Ventas et al. 1995) are plotted, and they are compared with those of the SCS granitoids and with the composition of mantle-derived rocks (M) (Taylor 1988). The distribution of the MME defines a trend broadly connecting the field of mantle-derived rocks to SCS granites, suggesting that mixing of basic magmas and crustal melts may account for this kind of enclave and for the local MME-rich facies of some granitic plutons (e.g. Moreno-Ventas et al. 1995). Nevertheless there is no isotopic indication for significant mantle contribution to the SCS geochemistry. As in other peraluminous Hercynian batholiths, the geochemistry of SCS granitoids reflects the composition of its crustal sources, the minor mafic component being of very limited importance (e.g. Di Vincenzo et al. 1996; Gerdes et al. 1998).

In a similar way, assimilation models to explain the origin of the most peraluminous SCS granites (i.e. CG types, Ugidos \& Recio 1993) are severely restricted, as shown by the contrast in isotopic composition between granites and related wall rocks (middle/upper crustal levels) and the lack of any mixing trend between them (Fig. 6). The (Sr, Nd, O) isotopic data of the SCS granites do not require a shallower crustal component.

\section{Magma generation}

Apart from the material source for any magmatic event, it is also important to discuss the source of heat energy for melting. Melt normally is not present within the lithosphere and must be produced by heating, lowering pressure, adding volatiles, or a combination of these mechanisms brought about by some tectonic event (Speer et al. 1994). In the case of the SCS granites, their relation to the thermal evolution of the Hercynian collision seems to be conclusive but, nevertheless, other hypotheses have arisen.

Heating by mafic magma underplating and consequent evolution through crustal interaction have been suggested to explain the origin of SCS granites (Pinarelli \& Rottura 1995; Moreno-Ventas et al. 1995; Castro et al. 1999). Theoretical models involving an important contribution of mantle-derived magmas in the genesis of the SCS batholith require a large volume of basic rocks, which is not present in the area. A minor involvement of coeval mafic magmas with the granitoids is enough to explain the presence of local intermingling and mafic microgranular enclaves in granitoids, as previously discussed. There is no evidence of basic material either eroded (sedimentary-related rocks) or hidden in deeper crustal levels. The xenolith suite of granulitic rocks from the lower crust is conclusive in this respect: $95 \%$ felsic metaigneous rocks, $5 \%$ pelites and rare charnockitic xenoliths (Villaseca et al. 1999). Geophysical data also support such a felsic lower crust beneath the SCS (Banda et al. 1981).

Large volumes of basic magmas are required to produce large granitic batholiths and, furthermore, basalt-induced crustal melting is rapid $\left(10^{2}-10^{3} \mathrm{y}\right.$, Huppert \& Sparks 1988). Thus large-scale and continuous basic magmatism would need to persist for more than $40 \mathrm{Ma}$ to explain the described Hercynian magmatic event.

The SCS metamorphic belt in the eastern areas (Sierra de Guadarrama) shows an increase in metamorphic grade towards the central block where the batholith crops out. The exposed metamorphic series locally attained $750-800^{\circ} \mathrm{C}$ at $4-6 \mathrm{kbar}$ $(1 \mathrm{kbar}=100 \mathrm{MPa})$ during the Hercynian metamorphic peak (mid-crustal granulitic terranes) but $\mathrm{P}-\mathrm{T}$ estimates on granulitic xenoliths record metamorphic conditions of around $900^{\circ} \mathrm{C}$ and $8-10 \mathrm{kbar}$ for the lower Hercynian crust (Villaseca et al 1999). These $\mathrm{P}-\mathrm{T}$ estimates are in accordance with a regional geothermal gradient of $30-40^{\circ} \mathrm{C} \mathrm{km}^{-1}$, which is slightly higher than those obtained in typical thermal models of crustal thickening during continental collision (Patiño Douce et al. 1990; Gardien et al. 1995). This could result from a combination of two factors (Villaseca et al. 1998a): (a) the marked felsic composition of the SCS crust which contains a high concentration of heat-producing radioactive elements, and (b) the considerable crustal thickening attained during collision, estimated to be around $70-80 \mathrm{~km}$, more than doubling the original thickness (Villaseca \& Barbero 1994). Temperatures in excess of $900{ }^{\circ} \mathrm{C}$ at the Moho permit significant partial melting of the felsic crustal materials: between $40-60 \%$ and liquid for pelitic rocks, and $5 \%$ to $35 \%$ liquid for quartzofeldspathic rocks (Gardien et al. 1995).

$\mathrm{P}-\mathrm{T}$ estimates for crystallisation of high-temperature minerals in SCS granitoids (probably close to their liquidus conditions, in some cases defining residual paragenesis, e.g. Casillas 1989; Eugercios 1994) are in agreement with thermal conditions during the Hercynian orogeny (Fig. 7). Magmatic epidote and muscovite are absent in granodiorites and monzogranites, only rare garnet (of grossular-almandine composition) or Al-rich hornblende indicates that SCS intrusives mostly crystallised at pressures lower than 6-8 kbar (Fig. 7). These P-T estimates plot close to the estimates made on restitic granulites 


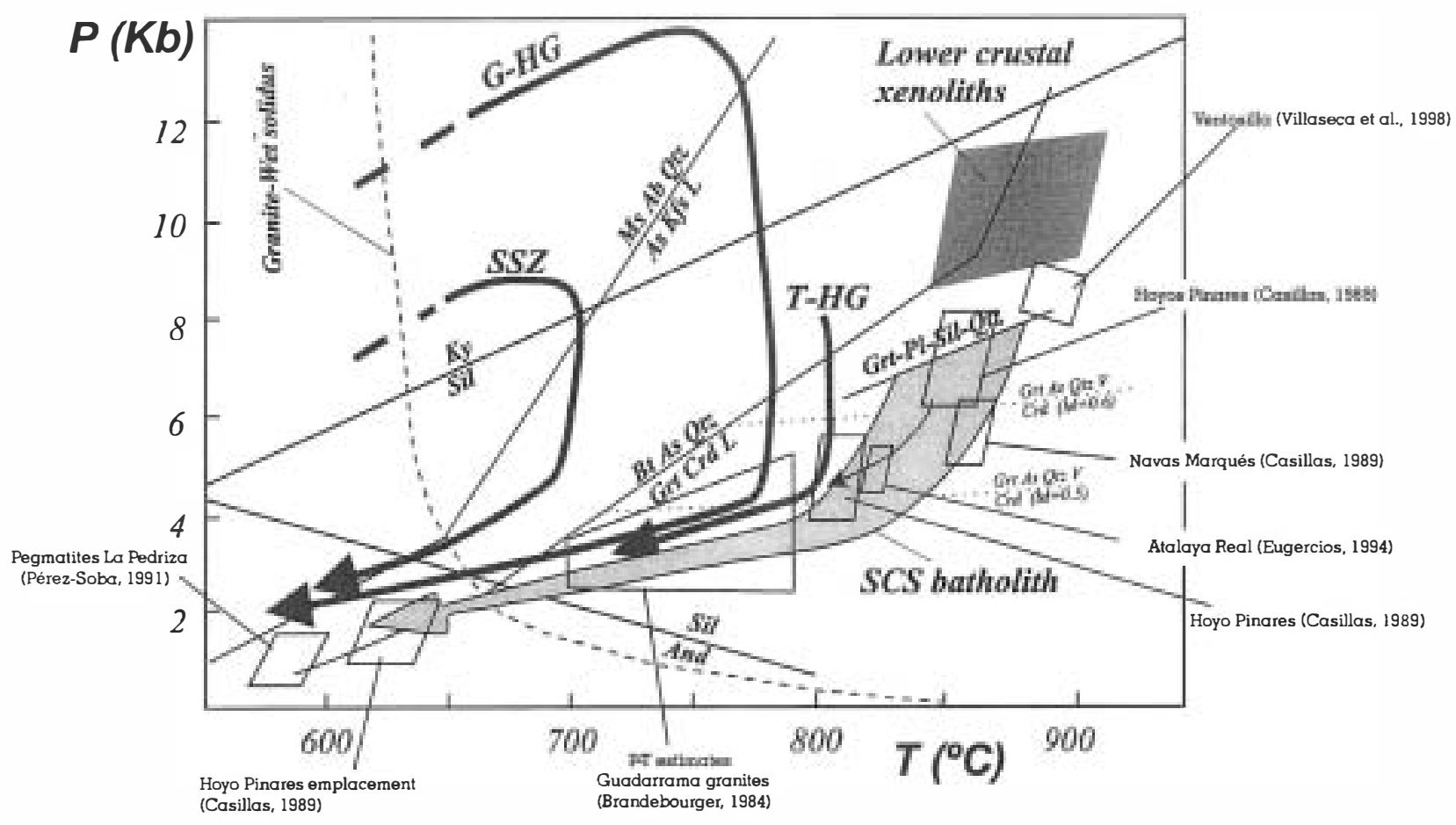

Figure 7 P-T diagram showing the estimated conditions during the generation and emplacement of the SCS granitcs; Grt-Pl-Sil-Qtz equilibrium is from Casillas (1989) for Hoyo de Pinares and related plutons; high P-T estimates in granites (Casillas 1989; Eugercios 1994; Villaseca et al. 1998b), are mainly based on Grt-Bt, Grt$\mathrm{Crd}, \mathrm{Ti}$ - and $\mathrm{Al}$-in-hornblende geothermobarometry, and are used to define the general P-T conditions of generation of the SCS batholith; emplacement conditions of the SCS batholith over a range of 4-2 kbar reflect exhumation during batholith emplacement, although a clear correlation between emplacement pressure and age has not been yet established; SSZ represents the P-T path of the sillimanite zone of Somosierra sector (E of SCS) (Escuder Viruete et al. 1998); G-HG represents the P-T path of high-grade areas of the Guadarrama sector from Villaseca \& Barbero (1994); T-HG represents the P-T path of the high-grade anatectic complex of Toledo (Barbero 1995); lower crustal estimates are from Villaseca et al. (1999); the mineralogical and chemical nature of SCS granites is consistent with a generation by crustal anatexis of peraluminous sources in the lowercrust (seetext); curve of granite-wet solidus from Johannes (1984); other curves and mineral symbols are from Spear et al. (1999).

from the SCS lower crust (Villaseca et al. 1999) suggesting the possibility of an attainment of equilibrium between them (Fig. 7). This is an additional support for the generation of these granitic magmas by crustai anatexis of felsic peraluminous rocks in the deeper crust. Hercynian granitoids could mainly represent recycling of older continental crust with no substantially new additions.

\section{Discussion}

The lack of significant compositional differences between the three granitic suites, maintained during a long period, suggests a similarity in nature of their source regions and conditions of magma generation. The similarity of REE patterns among monzogranitic rocks ranging in age from 325-280 Ma (Fig. 5) suggests that accumulation or removal of early crystallising phases did not greatly disturb the REE abundances. Therefore, the REE pattern must reflect the mineralogy of the source residue. Similarly, the narrow range of trace element ratios such as $\mathrm{Rb} / \mathrm{Zr}, \mathrm{Y} / \mathrm{Nb}$ or REE/Th among SCS monzogranites might be an indication of the sources involved. This suggests that all source residues contained feldspars (plagioclase and/ or $\mathrm{K}$-feldspar) in order to explain both the low $\mathrm{Sr}$ contents and the marked negative Eu anomaly in all parental granite types. This is in good agreement with the residual assemblages in granulitic xenoliths of the SCS lower crust (Villaseca et al. 1999).

The limited range of isotopic ratios shown by SCS granites suggests the involvement of very abundant and fertile litho- types. Two protoliths have these characteristics in the central segment of the Iberian Hercynian Belt. Metapelites have been described as protoliths involved in the genesis of certain anatectic granites during metamorphic peak (Barbero \& Villaseca 1992). Orthogneisses are also very common in the exposed metamorphic series and chemically they have closer ratios (at least in initial Nd signatures, Villaseca et al. 1998a) to the SCS granites. As also shown by Villaseca et al. (1999), felsic metaigneous protoliths are the most common lithology in lower crustal levels, as c. $95 \%$ of the granulitic xenolith suite is of this nature.

Although fertile crustal lithotypes are abundant in the SCS (quartzofeldspathic metaigneous rocks as better candidates for granite sources) it is paradoxical that in the chemistry of the granites there would not appear any reflection of evolution of melting conditions (depth of melting, residual phases, melt fraction, . . . etc.) with time. Would the constancy in LREE/ HREE ratios in SCS granites with time, reflect a constancy in protoliths and depth of partial melting? In continental margins the geochemical asymmetry of some batholiths in part reflects either the progressive involvement of thicker parts of the continental margin wedge or the depth of melting (Gromet \& Silver 1987). Similarly, in granitic plutonic complexes of more intracontinental settings, an evolution of melting depth with time has also been described (e.g. the Idaho Batholith, Norman et al. 1992). Moreover, in thermal orogenic models there is an evolution of melting levels with time (Patiño Douce et al. 1990; Thompson \& Connolly 1995). So, why is there not any important image in SCS granite chemistry of these changeable melting conditions? One factor explaining this would be the 
broad garnet stability field in quartzofeldspathic rocks. Garnet is the main mineral controlling HREE in granulite melting conditions for pelitic and felsic protoliths (Ayres \& Harris 1997). The garnet stability field is very broad for these lithotypes, ranging from middle to lower crustal levels (4-15 kbar, Spear et al. 1999). In other words, garnet is always present in the residual assemblage during partial melting in this Hercynian sector.

REE, Y, P, Zr and Th are also controlled by the presence of apatite, zircon, monazite or xenotime in the melting event (Watson 1985; Watt \& Harley 1993; Ayres \& Harris 1997). SCS granites seem to have resulted from disequilibrium melting of crustal protoliths, as their low total REE concentrations are much less than expected in dissolution models. Monazite is the main reservoir of REE in peraluminous rocks (where allanite is absent) (e.g. Nabelek \& Glascock 1995; Ayres \& Harris 1997). When considering REE modelling based on monazite solubility in partial melting processes (Montel 1993), no reasonable combination of T, $D$ or $\mathrm{H}_{2} \mathrm{O}$ solubility can reproduce the low REE concentrations in the SCS granites (Fig. 8). REE concentration in the melts is mostly conditioned by temperature, and to a lcsscr extent by melt composition ( $D$ factor) and water content (see Montel 1993). Using reasonable values for these parameters, the SCS granites had to show REE concentrations close to an average value of $620 \mathrm{ppm}$, intermediate value between $240 \mathrm{ppm}$ (for the more peraluminous granites with $D$ values c. 1.00 and low water contents of only $2 \mathrm{wt} \% \%$, at low temperature of melting: $850^{\circ} \mathrm{C}$ ) and $975 \mathrm{ppm}$ (for less peraluminous granites with $D$ values $c .1 \cdot 25$, undersaturated higher water contents of $5 \mathrm{wt} . \%$, at $900^{\circ} \mathrm{C}$ ). This indicates lack of saturation of granitic melts by monazite dissolution during melting. The same undersaturation is deduced for $\mathrm{Zr}$ using zircon dissolution modelling. Using this modelling for hydrous peraluminous granitic melts (Watson \& Harrison 1983), saturation must be around $500( \pm 200) \mathrm{ppm}$ in the melt, which is far from the lower concentration range shown by the SCS granites (Fig. 8).

This trace-element undersaturation has been interpreted as a consequence of two main factors: (a) heterogeneous distribution of accessory phases in the source and morphological

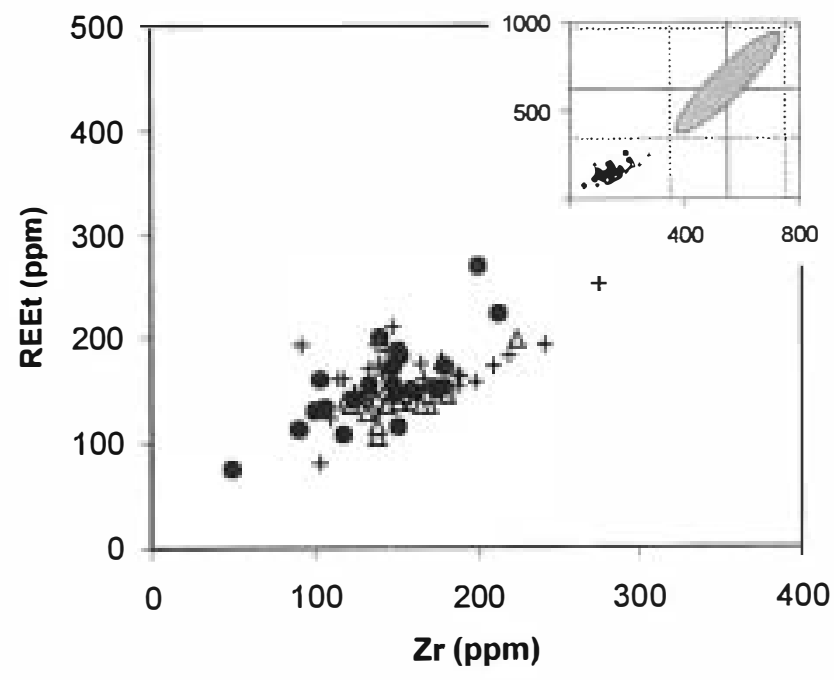

Figure 8 Plot showing total REE vs Zr contents in SCS granites (same symbols as in Fig. 3); inset shows estimated concentrations in granitic melts saturated with monazite and zircon (shaded field) at various temperatures $\left(850-900^{\circ} \mathrm{C}\right)$, water contents $(2-5 \mathrm{wt} . \%)$ and melt compositions ( $\mathrm{D}$ in the range $1-1 \cdot 25$ and $\mathrm{M} c .1 \cdot 3-1 \cdot 6)$ using the models of Montel (1993) and Watson \& Harrison (1983) (see text for further explanation); $\mathrm{Zr}$ and total REE contents in SCS granites are clearly lower than those predicted by solubility models. features that inhibit quick crystal dissolution, e.g. large crystals totally included in major phases, isolated from a partial melt and having few chances to be totally dissolved (Watt \& Harley 1993; Nabelek \& Glascock 1995); (b) melt segregation rates exceeding accessory phases dissolution rates (Sawyer 1991). Nevertheless, a significant amount of some trace elements resides in major phases (garnet, plagioclase, alkali feldspar) of granulitic restites. This would result in contrasting behaviour of these major phases during melting processes with respect to what occurs during crystallisation from felsic granitic melts (Reid 1990). In this respect, two factors point to compatible behaviour of some minor and trace elements in feldspars during melting under granulitic conditions: (i) SCS granulitic xenoliths are not depleted in REE, $\mathrm{P}$ or $\mathrm{Zr}$ contents (Villaseca et al. 1999), and (ii) feldspars are major carriers of LREE and P in granulites (Reid 1990; Bea 1996; Villaseca et al. 1999) (Fig. 9). A similar situation may be envisaged when residual garnet is involved. In this case, HREE and also $\mathrm{Zr}$ from xenotime and zircon dissolution may be transferred to the newly formed granulitic garnet (Bea \& Montero 1999; Fraser et al. 1997). So, trace element components from dissolution of accessory phases during melting are not necessarily partitioned to the melt fraction, as a substantial part would be introduced in the newly formed incongruent minerals of melting reactions. In any case, initial trace element geochemical variability in granite melts is severely reduced by the lack of attainment of equilibrium conditions during melting, because compositions are buffered compared to those expected by dissolution models.

Finally, when crustal melts derived from a range of sources do not subsequently have the opportunity to accumulate into large magma bodies (where efficient mixing could be enhanced) the granite massif will retain its chemical heterogeneity. This is well exemplified by felsic granitoids derived by low-melt fractions in short-lived magmatic systems such as the Himalayan and other leucogranites (Deniel et al. 1987; Krogstad \& Walker 1996; Searle et al 1997). In the same way, granitic plutons showing evidence of rapid rates of extraction, ascent and emplacement of individual melt batches, would inhibit widespread mixing between melts (Pressley \& Brown 1999). In central Spain, plutonic complexes have batholithic dimensions (Table 1), and lack sharp contacts between the monzogranitic internal units. SCS granitic plutons probably acquired definitive homogeneous geochemical features as a consequence of a complex combination of limited crustal sources in a geodynamic setting where melting conditions were maintained for a long time. This long-lived magmatic system, combined with ascent and emplacement rates where crystallisation of melt batches was slower than the rate of arrival of successive batches of melt, allowed the progressive growth of the plutonic complex and, consequently, enhanced the possibility of convection and physical mixing between similar melts from not very different sources. Thus the generation of voluminous and relatively chemically and isotopically homogeneous plutons is more likely. Nevertheless, the Atalaya Real massif shows increasing initial isotopic $\mathrm{Nd}$ ratios with increasing $\mathrm{SiO}_{2}$ content, suggesting that mixing of magmas derived from heterogeneous sources was not complete (Villaseca et al. 1998d). New geochemical studies combined with different isotopic systems are needed for better evaluation of these proposals.

\section{Conclusions}

The SCS is a remarkably homogeneous batholith showing a restricted range of geochemical granite types without any evolutionary pattern related to time. During Hercynian times 


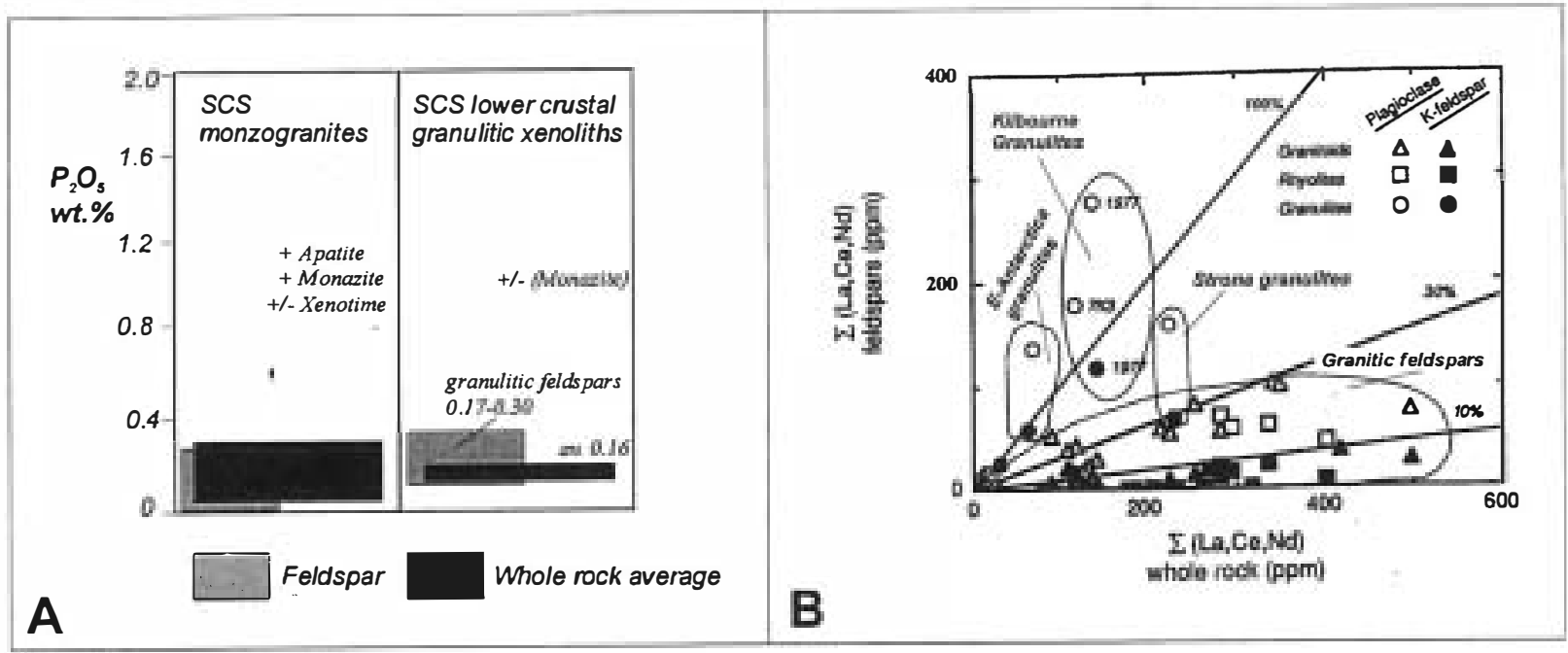

Figure 9 Comparison of $\mathrm{P}_{2} \mathrm{O}_{5}$ and LREE contents in feldspars and whole rocks from granitoids and granulites: (A) phosphorous contents in feldspars and whole rocks from SCS monzogranites (from our own data set) compared to data from lower crustal xenoliths (Villaseca et al. 1999); in these granulites phosphorous is mainly contained in feldspars in accordance with their generalised lack of phosphate phases. (B) LREE data from granitoids, rhyolites and granulites mainly based on the work of Reid (1990); other granulite data: Strona (Bea 1996) and EAntarctica (Watt \& Harley 1993); in lower crustal granulites most of the LREE are contained in residual feldspars attaining concentrations of $30-100 \%$ of the whole rock content; involvement of accessory phases in residual granulites is very low, again in accordance with their petrographic scarcity; as a consequence, dissolution of accessory phases during melting does not control trace element geochemistry of granitic melts when feldspars are abundant residual granulitic phases.

prealuminous granites with small variations in chemical composition, i.e. restricted range of ratios of $\mathrm{Na}_{2} \mathrm{O} / \mathrm{K}_{2} \mathrm{O}$ $(0 \cdot 60-0 \cdot 95), \mathrm{K} / \mathrm{Rb}(140-240),(\mathrm{La} / \mathrm{Yb})_{\mathrm{n}}(6-13)$ and $\mathrm{Eu} / \mathrm{Eu}^{*}$ $(0 \cdot 34-0 \cdot 62)$, intruded continuously in the SCS. This constancy in chemical characteristics of monzogranites is also reflected in their isotopic signatures: most have initial ${ }^{87} \mathrm{Sr} /{ }^{86} \mathrm{Sr}$ ratios in the range $0.7073-0.71229$, initial $\varepsilon \mathrm{Nd}$ values varying between -5.4 and -6.6 and $\delta^{18} \mathrm{O}$ values in the narrow range 8.9 $9.6 \%$. In addition to this scenario, sporadic intrusions of granitic magma batches displaying different geochemical signatures, either with a stronger pelitic source derivation (e.g. Pedrobernardo pluton, Bea et al. 1994) or from intermediatecomposition igneous sources (e.g. Ventosilla pluton, Villaseca et al. 1998b) are also observed.

This monotonous granitic batholith is in marked contrast with other Hercynian batholiths (French Massif Central, NE Bohemian Massif) or batholiths from intracontinental settings (e.g. Cordillera Blanca, Idaho, Colville) where either a variable mantle contribution (or more refractory components), or a variation in melting depth with time leads to more geochemically complex granitic batholiths. The SCS batholith clearly contrasts with the geochemically segmented and asymmetrically composed cordilleran batholiths of plate margins (e.g. Peruvian Coastal Batholith, Peninsular Ranges Batholith).

Some factors related to the Hercynian continental collision have contributed to the origin of this long-lived homogeneous magmatic system. The main factor is the involvement of a limited range of crustal sources in the origin of the batholith. Geochemical and isotopic features of SCS granitoids are compatible with felsic lower crustal sources. The essentially felsic nature of this crustal segment and the limited basic input during orogenesis leads to a restricted variety of granitic magma batches with a limited range of isotopic compositions.

When a limited range of sources are involved in the genesis of a batholith, melting conditions are also more constrained.
Uniformity in residual mineral assemblages (feldspars and garnet are always present in the granulitic residua), combined with a lack of attainment of equilibrium conditions during accessory phase dissolution in the crustal melting process, is suggested. Granitic melts never reach saturation contents in those trace elements controlled by these phases (REE, Th, P, $\mathrm{Y}, \mathrm{Zr}$. . .), restricting their chemical variability. This was in part due to the important role played by some major phases during melting under granulitic conditions, because a large fraction of some trace elements (LREE, P . . .) is hosted in residual feldspars.

Anatectic magma batches derived from a limited variety of interlayered crustal sources tend to obscure (and homogenise) their original chemical differences by mixing in mid-crustal major magma chambers. It has been suggested that similar processes of efficient mixing of melts from more than one source occur in other productive long-lived magmatic systems (e.g. mid-ocean ridges: Hess 1989; Marsh 1996).

\section{Acknowledgements}

We are grateful to the organisers of this Fourth Hutton Symposium, and Professor B. Barbarin in particular, for giving us the opportunity to participate in this meeting. We acknowledge Drs Calvin Barnes, Bernard Barbarin and an anonymous reviewer for their constructive comments. Drs Edurne Martinez and specially Luis Barbero are thanked for their corrections and suggestions to a previous version of our paper. Drs Clemente Recio and Jose María Ugidos (Servicio General de Análisis de Isótopos Estables, Universidad de Salamanca) are thanked for their diligence in the performance of oxygen isotope analyses. This work is included in the objectives of and supported by the PB96-0661 DGES project of the Spanish MEC. 


\section{References}

Atherton, M. P., McCourt, L. M., Sanderson, L. M. \& Taylor, W. P. 1979. The geochemical character of the segmented Peruvian Coastal Batholith and associated volcanics. In Atherton, M. P. \& Tarney, J. (eds) Origin of granite batholiths: geochemical evidence 45-64. Orpington, Kent: Shiva Publishing.

Ayres, M. \& Harris, N. 1997. REE fractionation and Nd-isotope disequilibrium during crustal anatexis: constraints from Himalayan leucogranites. Chemical Geology 139, 249-69.

Banda, E., Suriñachs, E., Aparicio, A., Sterra, J. \& Ruiz de la Parte, E. 1981. Crust and upper mantle structure of the Central Iberian Meseta (Spain). Geophysical Journal of the Royal Astronomical Societ y 67, 779-89.

Barbero, L. 1995. Granulite facies metamorphism in the Anatectic Complex of Toledo (Spain): Late Hercynian tectonic evolution by crustal extension. Journal of the Geological Society of London $152,365-82$

Barbero, L. \& Rogers, G. 1999. Implications of U-Pb monazite ages from syn-orogenic granites of the anatectic complex of Toledo (Spain) in the evolution of the central part of the Hercynian Iberian Belt. In Barbarin, B. (ed). The Origin of Granites and Related Rocks, Fourth Hutton Symposium Abstracts. Documents du B.R.G.M. 290, 203.

Barbero, L. \& Villaseca, C. 1992. The Layos granite, hercynian Complex of Toledo (Spain): an example of parauthocthonous restiterich granite in a granulitic area. Transactions of the Royal Society of Edinburgh: Earth Sciences 83, 127-38.

Bea, F. 1985. Los granitoides hercinicos de la mitad occidental del batolito de Avila (sector de Gredos). Aproximación mediante el concepto de superfacies. Revista de la Real Academia de Ciencias Exactas, Fisicas y Naturales 79, 549-72.

Bea, F. 1996. Residence of REE, Y, Th and U in granites and crustai protoliths; implications for the chemistry of crustal melts. Journal of Petrology 37, 521-52.

Bea, F., Pereira, M.D., Corretgé, L. G. \& Fershtater, G. B. 1994. Differentiation of strongly peraluminous, perphosphorus granites: The Pedrobernardo pluton, central Spain, Geochimica et Cosmochimica Acta 58, 2609-27.

Bea, F., Montero, P. \& Molina, J. F. 1999. Mafic precursors, peraluminous granitoids, and late lamprophyres in the Avila Batholith: A model for the generation of Variscan batholiths in Iberia. Journal of Geology 107, 399-419.

Bea, E. \& Montero, P. 1999. Behaviour of accessory phases and the redistribution of $\mathrm{Zr}$, REE, $\mathrm{Y}$, Th, and $\mathrm{U}$ during metamorphism and partial melting of metapelites in the lower crust: an example from the Kinzigite Formation of Ivrea-Verbano, NW Italy. Geochimica et Cosmochimica Acta 63, 1133-53.

Bellido, F. 1979. Estudio petrológico y geoquímico del plutón de La Cabrera (Ph.d. Thesis, Universidad Complutense de Madrid).

Brandebourger, E. 1984. Les granitoides hercyniens tardifs de la Sierra de Guadarrama (Systeme Central Espagne). Pétrographie et geochimie (Ph.D. Thesis, Université de Lorraine).

Casillas, R. 1989. Las asociaciones plutonicas tardihercinicas del sector occidental de la Sierra de Guadarrama, Sistema Central Espanol, (Las Navas del Marques-San Martin de Valdeiglesias). Petrologia geoquimica, genesis y evolucion (Ph.D. Thesis, Universidad Complutense de Madrid).

Casillas, R., Vialette, Y., Peinado, M., Duthou, J. L. \& Pin, C. 1991. Ages et caracteristiques isotopiques ( $\mathrm{Sr}-\mathrm{Nd}$ ) des granitoides de la Sierra de Guadarrama occidentale (Espagne). Abstract Séance spécialisée de la Société Géologique de la France a la mémoire de Jean Lameyre.

Castro, A., Patiño Douce, A. E., Corretgé, L. G., de la Rosa, J. D., El-Biad, M. \& El-Hmidi, H. 1999. Origin of peraluminous granites and granodiorites, Iberian Massif, Spain: an experimental test of granite petrogenesis. Contributions to Mineralogy and Petrology 135, 255-76.

Chappell, B. W. 1999. Aluminium saturation in I- and S-type granites and the characterization of fractionated haplogranites. Lithos $\mathbf{4 6}$, $535-51$.

Chappell, B. W., White, A. J. R. \& Williams, I. S. 1991. A transverse section through granites of the Lachlan Fold Belt. Second Hutton Symposium Excursion Guide. Record 1991/22 BMR, Canberra.

Debon, F. \& Le Fort, P. 1983. A chemical-mineralogical classification of common plutonic rocks and associations. Transactions of the Royal Society of Edinburgh: Earth Sciences 73, 135-49.

Deniel, C., Vidal, P., Fernandez, A., Le Fort, P. \& Peucat, J. J. 1987. Isotopic study of the Manaslu granite (Himalaya, Nepal): inferences on the age and source of Himalayan leucogranites. Contributions to Mineralogy and Petrology 96, 78-92.
Di Vincenzo, G., Andriessen, P. A. M. \& Ghezzo, C. 1996. Evidence of two different components in a Hercynian peraluminous cordieritebearing granite: the San Basilio intrusion (Central Sardinia, Italy). Journal of Petrology 37, 1,175-206.

Downes, H., Shaw, A., Williamson, B. J. \& Thirlwall, M. F. 1997. $\mathrm{Sr}, \mathrm{Nd}$ and $\mathrm{Pb}$ isotopic evidence for the lower crustal origin of Hercynian granodiorites and monzogranites, Massif Central, France. Chemical Geology 136, 99-122.

Escuder Viruete, J., Hernáiz Huerta, P. P., Valverde-Vaquero, P., Rodríguez Fernández, R. \& Dunning, G. 1998. Variscan syncollisional extension in the Iberian Massif: structural, metamorphic and geochronological evidence from the Somosierra sector of the Sierra de Guadarrama (Central Iberian Zone, Spain). Tectonophysics 290, 87-109.

Eugercios, L. 1994. Petrología y geocronologia Rb-Sr de plutones del sector central de la Sierra de Guadarrama (macizos de Alpedrete y de la Atalaya Real) (Tesis Licenciatura, Universidad Complutense de Madrid).

Fraser, G., Ellis, D. \& Eggins, S. 1997. Zirconium abundance in granulite-f acies minerals, with implications for zircon geochronology in high-grade rocks. Geology 25, 607-10.

Gardien, V., Thompson, A. B., Grujic, D. \& Ulmer, P. 1995. Experimental melting of biotite + plagioclase + quartz \pm muscovite assemblages and implications for crustal melting. Journal of Geophysical Research 100, 15,581-91.

Gerdes, A., Wörner, G. \& Henk, A. 1998. Thermal and geochemical evidence for granite generation and HT-LP metamorphism by crustal stacking and radiogenic heating (the Variscan southern Bohemian massif). Acta Universitatis Carolinae-Geologica 42, 254.

Gromet, L. P. \& Silver, L. T. 1987. REE variations across the Peninsular Ranges batholith: Implications for batholithic petrogenesis and crustal growth in magmatic arcs. Journal of Petrology 28, $75-125$.

Gutiérrez Marco, J. C., San José, M. A. \& Pieren, A. P. 1990. CentralIberian Zone. Post-Cambrian Paleozoic stratigraphy. In Dallmeyer, R. D. \& Martinez García, E. (eds) Pre-Mesozoic Geology of Iberia $160-71$. Berlin: Springer.

Hernando, S., Schott, J. J., Thuizart, R. \& Montigny, R. 1980. Age des andésites et de sédiments interstratifiés de la région d'Atienza (Espagne): étude stratigraphique, géochronologique et paléomagnetique. Sciences Géologiques, Strasbourg, Bulletin 33, 119-28.

Herreros, V. 1998. Petrología y geoquímica de los granitoides del sector oriental de Gredos (Sistema Central Español) (Ph.D. Thesis, Universidad Complutense de Madrid).

Hess, P. C. 1989. Origins of igneous rocks. Cambridge, MA: Harvard University Press.

Huppert, H. E. \& Sparks, R. S. J. 1988. The generation of granitic magmas by intrusion of basalt into continental crust. Journal of Petrology 29, 599-624.

Isihara, S. \& Matsuhisa, Y. 1999. Oxygen isotopic constraints on the geneses of the Miocene Outer Zone granitoids in Japan. Lithos 46, 523-34.

Johannes, W. 1984. Beginning of melting in the granite system Ab-AnOr- $\mathrm{An}-\mathrm{H}_{2} \mathrm{O}$. Contributions to Mineralogy and Petrology 84, 26473.

Krogstad, E. J. \& Walker, R. J. 1996. Evidence of heterogeneous crustal sources: the Harney Peak granite, south Dakota, U.S.A. Transactions of the Royal Society of Edinburgh: Earth Sciences 87, 331-7.

Marsh, B. D. 1996. Solidification fronts and magmatic evolution. Mineralogical Magazine 60, 5-40.

Martín Romera, C., Villaseca, C. \& Barbero, L. 1999. Materiales anatécticos en el área de Sotosalbos (Segovia, Sierra de Guadarrama). Caracterización petrológica, geoquimica e isotópica ( $\mathrm{Sr}$, $\mathrm{Nd})$. II Congreso Ibérico de Geoquímica, Lisboa (Portugal), 32932.

Montel, J. M. 1993. A model for monazite/melt equilibrium and application to the generation of granitic magmas. Chemical Geology $110,127-46$

Moreno-Ventas, I., Rogers, G. \& Castro, A., 1995. The role of hybridization in the genesis of Hercynian granitoids in the Gredos Massif, Spain: inferences from $\mathrm{Sr}-\mathrm{Nd}$ isotopes. Contributions to Mineralogy and Petrology 120, 137-49.

Nabelek, P. I. \& Glascock, M. D. 1995. REE-depleted leucogranites, Black Hills, south Dakota: a consequence of disequilibrium melting of monazite-bearing schists. Journal of Petrology 36, 1,055-71.

Norman, M. C., Leeman, W. P. \& Mertzman, S. A. 1992. Granites and rhyolites from the northwestern U.S.A.: temporal variation in magmatic processes and relations to tectonic setting. Transactions of the Royal Society of Edinburgh: Earth Sciences 83, 71-81. 
Patiño Douce, A. E., Humphreys, D. E. \& Johnston, A. D. 1990. Anatexis and metamorphism in tectonically thickened crust exemplified by the Sevier Hinterland, Western North America. Earth and Planetary Science Letters 97, 290-315.

Pereira, M. D. 1992. El complejo Anatéctico de la Peña Negra (Batolito de Avila): un estudio de la anatexia cortical en condiciones de baja presión (Ph.D. Thesis, Universidad de Salamanca).

Pérez-Soba, C. 1991. Petrologia y geoquímica del macizo granítico de La Pedriza (Ph.D. Thesis, Universidad Complutense de Madrid).

Petford, N. \& Atherton, M. 1996. Na-rich partial melts from newly underplated basaltic crust: the Cordillera Blanca Batholith, Peru. Journal of Petrology 37, 491-521.

Pin, C. \& Duthou, J. L. 1990. Sources of Hercynian granitoids from the French Massif Central: inferences from Nd-isotopes and consequences for crustal evolution. Chemical Geology 83, 28196.

Pinarelli, L. \& Rottura, A., 1995. Sr and Nd isotopic study and Rb-Sr geochronology of the Béjar granites, Iberian Massif, Spain. European Journal of Mineralogy 7, 577-89.

Pressley, R. A. \& Brown, M. 1999. The Phillips pluton, Maine, USA: evidence of heterogenous crustal sources and implications for granite ascent and emplacement mechanisms in convergent orogens. Lithos 46, 335-66.

Recio, C., Fallick, A. E. \& Ugidos, J. M. 1992. A stable isotopic $\left(\delta^{18}\right.$ O, $\delta \mathrm{D})$ study of the late-Hercynian granites and their host-rocks in the Central Iberian Massif (Spain). Transactions of the Royal Society of Edinburgh: Earth Sciences 83, 247-57.

Reid, M. R. 1990. Ion probe investigation of rare earth element distribution and partial melting of metasedimentary granulites. In Vielzeuf, D. \& Vidal, Ph. (eds) Granulites and crustal evolution, 507-22. Dordrecht: Kluwer.

Rollura, A., Bargossi, G. M., Caironi, V., D'Amico, C. \& Maccarone, E. 1989. Petrology and geochemistry of late-hercynian granites from the Western Central System of the Iberian Massif. European Journal of Mineralogy 1, 667--83.

Sawyer, E. W. 1991. Disequilibrium melting and the rate of melt-residuum separation during migmatization of mafic rocks from the Grenville Front, Quebec. Journal of Petrology 32, 701-38.

Searle, M. P., Parrish, R. R., Hodges, K. V., Hurford, A., Ayres, M. W. \& Whitehouse, M. J. 1997. Shisha Pangma leucogranite, South Tibetan Himalaya: field relations, geochemistry, age, origin, and emplacement. Journal of Geology 105, 295-317.

Siebel, W., Höhndorf, A. \& Wendt, I. 1995. Origin of late Variscan granitoids from NE Bavaria, Germany, exemplified by REE and Nd isotope systematics. Chemical Geology 125, 249-70.

Spear, F. S., Kohn, M. J. \& Cheney, J. T. 1999. $P-T$ paths from anatectic pelites. Contributions to Mineralogy and Petrology 134, 17-32.

Speer, J. A., McSween, H. Y. Jr. \& Gates, A. E. 1994. Generation, segregation, ascent, and emplacement of Alleghanian plutons in the southern Appalachians. Journal of Geology 102, 249-67.

Taylor, H. P. Jr. 1988. Oxygen, hydrogen, and strontium isotope constraints on the origin of granites. Transactions of the Royal Society of Edinburgh: Earth Sciences 79, 317-38.
Thompson, A. B. \& Connolly, J. A. D. 1995. Melting of the continental crust: some thermal and petrological constraints on anatexis in continental collision zones and other tectonic settings. Journal of Geophysical Research 100, B8, 15,565-79.

Ugidos, J.M. \& Recio, C. 1993. Origin of cordierite-bearing granites by assimilation in the Central Iberian Massif (CIM), Spain. Chemical Geology 103, 27-43.

Ugidos, J. M., Valladares, M. I., Recio, C., Rogers, G., Fallick, A. E. \& Stephens, W. E. 1997. Provenance of Upper Precambrian-Lower Cambrian shales in the Central Iberian Zone, Spain: evidence from a chemical and isotopic study. Chemical Geology 136, 55-70.

Villaseca, C., Barbero, L., Huertas, M. J., Andonaegui, P. \& Bellido, F 1993. A cross-section through Hercynian granites of Central Iberian Zone. Excursion guide, C.S.I.C. Madrid.

Villaseca, C., Eugercios, L., Snelling, N. J., Huertas, M. J. \& Castellón, T. 1995. Nuevos datos geocronológicos ( $\mathrm{Rb}-\mathrm{Sr}, \mathrm{K}-\mathrm{Ar})$ de granitoides hercinicos de la Sierra de Guadarrama. Revista Sociedad Geológica de España 8, 129-40.

Villaseca, C., Barbero, L. \& Rogers, G. 1998a. Crustal origin of Hercynian peraluminous granitic batholiths of central Spain: petrological, geochemical and isotopic ( $\mathrm{Sr}, \mathrm{Nd}$ ) arguments. Lithos 43, 55-79.

Villaseca, C., Barbero, L., Reyes, J. \& Santos Zalduegui, J. F. 1998b. Nuevos datos petrológicos, geocronología $(\mathrm{Rb}-\mathrm{Sr})$ y geoquímica isotópica ( $\mathrm{Sr}, \mathrm{Nd}$ ) del plutón de Ventosilla (Sierra de Guadarrama, Sistema Central Espanol). Geogaceta 23, 169-72.

Villaseca, C., Barbero, L. \& Herreros, V. 1998c. A re-examination of the typology of peraluminous granite types in intracontinental orogenic belts. Transactions of the Royal Society of Edinburgh: Earth Sciences 89, 113-19.

Villaseca, C., Barbero, L., Rogers, G., Reyes, J. \& Santos Zalduegui, J.F. 1998d. Nd isotopic heterogeneity in late-Hercynian granitic plutons from Central Spain. Geogaceta 23. 165-68.

Villaseca, C., Downes, H., Pin, C. \& Barbero, L. 1999. Nature and composition of the lower continental crust in central Spain and the granulite-granite linkage: inferences from granulitic xenoliths. Journal of Petrology 40, 1,465-96.

Villaseca, C. \& Barbero, L. 1994. Estimación de las condiciones del metamorfismo hercínico de alta presión de la Sierra de Guadarrama. Geogaceta $16,27-30$.

Watson, E. B. 1985. Henry's law behaviour in simple systems and in magmas: Criteria for discerning concentration-dependent partition coefficients in nature. Geochimica et Cosmochimica Acta 49 917-23.

Watson, E. B. \& Harrison, T. M. 1983. Zircon saturation revisited: temperature and compositional effects in a variety of crustal magma types. Earth and Planetary Science Letters 64, 295-304.

Watt, G. R. \& Harley, S. L. 1993. Accessory phase controls on the geochemistry of crustal melts and restites produced during waterundersaturated partial melting. Contributions to Mineralogy and Petrology 114, 550-66.

Wildberg, H. G. H., Bischoff, L. \& Baumann, A. 1989. U-Pb ages of zircons from meta-igneous and metasedimentary rocks of the Sierra de Guadarrama: implications for the Central Iberian crustal evolution. Contributions to Mineralogy and Petrology 103, 253-62.

CARLOS VILlASECA and VÍCTOR HERREROS, Dpt. Petrologia y Geoquímica, Fac. CC.

Geológicas, Universidad Complutense, 28040 Madrid, Spain; e-mail: granito@eucmax.sim.ucm.es

MS received 21 September 1999. Accepted for publication 9 May 2000. 


.

